\title{
26. Enhancing Collaborative Management in the Basin
}

\author{
Katherine A. Daniell
}

\begin{abstract}
Appropriate policy in a democracy is determined through a process of political debate. The right course of action is always a matter of choice, never of fact.
\end{abstract}

— Davidoff (1965:331)

\section{Introduction}

This chapter examines the potential benefits and costs of enhancing collaborative planning and management practices in the Murray-Darling Basin (MDB), relative to the current approach being taken at a federal level since the creation of the Water Act 2007 and the Murray-Darling Basin Authority (MDBA). In particular, the opportunities and challenges of increasing stakeholder engagement in water reform and planning processes will be investigated. A brief analysis of knowledge and expertise available for organising and implementing engagement activities to support effective collaborative planning and management practices will be provided, along with suggestions on how such knowledge and expertise might best be used to enhance the current reform process.

\section{Challenges of Water Management: The need for collaborative approaches}

Each person values water in different ways. Many sources of water are likely to be valued concurrently for providing basic life-support functions such as for drinking, sanitation and food production, as well as for maintaining ecosystem health, a range of economic livelihoods and personal, cultural and spiritual wellbeing. Given these multiple and competing values for water-in particular, in a world of rapidly increasing population, environmental degradation and globalised telecommunications - the management of water is an increasingly political process. Recognising the political and value-based nature of water management is the key to successfully developing institutions and types of governance that allow the complex, uncertain and conflict-ridden situations seen in today's water basins to be successfully navigated (Syme and HatfieldDodds 2007). The political nature of contemporary water management is often 
characterised by a process of deciding how available water should or could be used and shared between a variety of stakeholders and the environment, and conflict resolution amongst these stakeholders ${ }^{1}$ (Delli Priscoli and Wolf 2009).

Under such conditions, traditional forms of centralised technocratic or 'command-and-control' management and reliance on engineering solutions and technologies are now typically considered insufficient for most water systems (Gleick 2000). One of the key reasons for this is that it is increasingly rare that individuals or governments have the capacity to make and implement their own water-management decisions without the help of other stakeholders, as power and resources for managing water systems are increasingly distributed. For this practical reason and other key reasons such as promoting thriving democracy (Dryzek 1990; Fischer 1990, 2000), it is imperative, rather than optional, that the development of water policies and their management and implementation plans be developed in an inclusive and collaborative way with a full range of management agencies, community stakeholders and members of the scientific community (Dietz et al. 2003; Loucks 1998; Thomas 2004). In this way, plans can be based on the best available scientific and stakeholder knowledge, with valuesbased decisions and management agreements collectively negotiated to ensure sufficient stakeholder 'buy-in' and capacity to successfully implement them.

This need to acknowledge the key roles that values play in water management and the need for a participatory or collaborative approach are reiterated in almost every recent well-known international water document, such as the Dublin Statement, which outlined that '[w]ater development and management should be based on a participatory approach, involving users, planners and policy makers at all levels' (ICWE 1992). Improving the uptake of this approach has been hampered in some quarters, however, by technocracies unwilling to give up some of their power for the benefit of water systems, and by a range of other issues such accountability, legitimacy and lack of understanding of how 'participatory' or collaborative approaches can be implemented (Tan et al. 2008). As Ingram and Schneider (1999: 27) stated more than 10 years ago, 'The most fundamental flaw in contemporary water policy is that many value questions in which ordinary citizens have a great interest, are being framed as technical questions.' Failing to understand the importance of developing inclusive stakeholder water-management processes and plans that are not only scientifically validated but broadly stakeholder legitimated (Landry et al. 1996)and enabling institutional infrastructure and facilitating environments to support these processes - has been seen as one of the main routes to inadequate plan implementation, continued water-system damage and conflict (Delli Priscoli 2003).

1 Stakeholders are considered as people, institutions or organisations that have a stake in the outcome of decisions related to water management, as they are directly affected by the decisions made or have the power to block or influence the decision-making process (Nandalal and Simonovic 2003). 


\section{Recent Reforms in the Murray-Darling Basin: A move to centralised control}

The bipartisan-supported federal water-reform process linked to the Water Act 2007, the creation of the MDBA and the $\$ 12.9$ billion Water for the Future plan presents a historic opportunity for investing in improved water-management practices, infrastructure and monitoring across Australia. Following a long line of management reforms in the MDB (see Connell 2007) - the more recent of which have made efforts to address issues of over-allocation of basin water resources and to restore environmental health to key environmental assetsthese new reforms seek, in part, to overcome perceived impasses and protracted negotiations that occurred in the Murray-Darling Basin Ministerial Council (the political forum invested with powers to make decisions for the Basin as a whole under the 1992 Murray-Darling Basin Agreement). To this end, decision-making power for the acceptance of the Murray-Darling Basin Plan, which will set sustainable diversion limits for water withdrawals and interceptions across the Basin, has been invested in a single federal minister. The minister is informed by the work and recommendations of the independent MDBA, a Basin Officials Committee, a Basin Community Committee and the new slimmed-down version of the Murray-Darling Basin Ministerial Council, which the federal minister also chairs.

The first incarnation of these reforms under the Howard Government-in particular, the National Plan for Water Security - marked a significant shift from the direction of previous reforms that had moved to treat the environmental, economic and social issues of water, land and environmental management in the Basin in an integrated manner through both collaborative and market mechanisms. The Howard reforms put the focus instead on centralised authority, infrastructure efficiency improvements and using economic instrumentsincluding water buybacks - in an attempt to ensure water-supply security and, in the process, Australian economic security. With the instalment of the Rudd-Gillard Government in 2008 and its Water for the Future plan, many of the initiatives of the Howard plan were maintained, but the priorities were re-badged as 'taking action on climate change, using water wisely, securing water supplies and supporting healthy rivers' (Wong 2008). Attempts were also made to alter the tone of the reforms from a technocratic and directive federal management intervention to one that reflected a more integrated and cooperative management style. For example, as stated by the then Minister for Climate Change and Water, Penny Wong (2008), at the presentation of the Plan: 'It is imperative for Commonwealth, state and local government[s] to share a common understanding of the problems in water and respond in a comprehensive and coordinated way.' 
Working under the Water Act 2007-drafted during the Howard administration - the MDBA has, however, taken the decision to pursue a more minimalist approach to cooperation and collaboration with other levels of government, regional management groups and local stakeholders. It appears that under the strict time pressures for the development of the Murray-Darling Basin Plan and the need to base the plan on the 'best available science', the MDBA worked to commission and collate large numbers of studies from consultants and academics, gather data, reports and models from State governments and to go about the synthesis work, analyses and choice of options for the plan inhouse, with a minimal amount of external consultation. ${ }^{2}$ An objective of such a process design could have been to limit the power of certain stakeholder or lobby groups opposed to any significant change. Whether such an approach is actually capable of achieving desired changes is, however, highly questionable if such groups have enough political power to block or upset the process in other ways (Daniell 2008; Fischer 2000).

\section{Understanding Preliminary Reactions to the MDBA Planning Approach}

This centralised technocratic approach that has appeared in practice - although supported by some stakeholders, including environmentalists, economists and government officials, who consider that the only way of restoring health to the Basin's ecosystems is by imposing cuts to water allocations and not allowing 'lobby' groups to intervene in the process - is far from supported by all. In particular, the lack of transparency of the planning process in clarifying underlying assumptions on which synthesis and planning decisions are made, and the common lack of openness to engage in discussions about these assumptions - so that community members and other land and water managers at different administrative levels can understand them - have received widespread criticism from, and distressed many of, the MDB's stakeholders. ${ }^{3}$

Until these reforms, many of the natural-resource management (NRM) processes in the MDB - especially over the past couple of decades - have aimed to be of a predominantly cooperative or collaborative nature (Bellamy et al. 2002; Boully 2004; Margerum 2008; SCEH 2000; Tan et al. 2008). In particular, at a local level (for example, through Landcare and integrated catchment management groups) and at a regional level (for example, through the NRM regional bodies), stakeholders have been encouraged through higher-level management groups (for example, the Community Advisory Committee linked to the former MDB Ministerial Council)

2 See the Basin Plan Knowledge and Information Directory for an overview of commissioned and collated information that has informed the development of the Basin Plan: <http://thebasinplan.mdba.gov.au/bpkid/> 3 See, for example, the comments stemming from the community information session tour: <http://www. mdba.gov.au/communities/latest-news> 
and funding programs (for example, the Federal Government's Natural Heritage Trust) to become actively involved in developing knowledge of, support for, and implementation and monitoring of reform programs such as the National Action Plan for Salinity and Water Quality and The Living Murray First Step. None of these programs has been immune to criticism, and a number of authors have suggested how the engagement mechanisms and governance arrangements could be further improved (Bellamy et al. 2002; Crase et al. 2005; Marshall and Stafford Smith 2010). Criticism came as many of these processes did not reach all of the 'ideal' outcomes that these collaborative approaches aim for - such as: increased social and political capital; agreement on information and shared understandings; ending stalemates; developing high-quality agreements; costeffective decision making; inciting learning and change beyond the original participating stakeholders; driving innovation; creating a cascade of changes in attitudes, behaviours and actions; and fostering institutions and practices that involve flexibility and networks (Connick and Innes 2001). Nevertheless, many positive advances were still made with relatively meagre resources relative to the magnitude of the issues facing the Basin, and the governance arrangements were often used in international discussion as a best-practice example of cooperative or collaborative trans-boundary water management (Delli Priscoli and Wolf 2009).

The large injection of funds coupled with the recent reforms (the Water Act 2007 and the Water for the Future plan) to transfer certain powers to the Federal Government was therefore welcomed by many stakeholders, who saw it as a potential means for strengthening their existing capacity to effect positive change in their regions and communities. Perceptions were quick to change, however, when stakeholders realised that the MDBA was planning to develop the plan largely 'in-house' with seemingly little regard for understanding the existing local, regional and State knowledge, networks and experience. This exclusion process and perceived disrespect for stakeholder knowledge and management experience were key drivers of a range of negative feelings and criticism directed at the MDBA and the Federal Government. For example, Leith Boully, Chair of the previous Murray-Darling Basin Ministerial Council's Community Advisory Committee, in a public lecture at the Australian Academy of Sciences for the Water Management Options for Urban and Rural Australia series in July 2010, expressed her feelings:

I'm angry that the Canberra machine does not seem to care about the impacts of water reform on real people in real communities. As an irrigator, and member of a community in the Lower Balonne, I no longer feel that the contribution I make to society is valued. Rather, I'm intensely aware of the disdain that the city's chardonnay set treats us with. I'm powerless to do anything about that. 
She is certainly not alone, as other State government officials and catchment managers, who are less able to publicly express their opinions, also state in private their concerns and feelings of disempowerment experienced from being largely excluded from the Basin planning process that they care about. In particular, they express their disappointment in not being able to contribute their knowledge or energy to enhance the reform process, and not being able to work through the uncertainties and challenges associated with the new Basin Plan with their constituents to build community understanding.

Curious observers and researchers in a range of water-management, governance and stakeholder-engagement areas have also been watching this reform process unfold with intense interest, as the move back to a technocratic 'command-andcontrol' type approach and the separation of water from land managementtogether with the use of market mechanisms - appear very different from currently promoted 'best-practice' approaches to water governance and management outlined at the beginning of this chapter.

\section{A Preliminary Attempt by the MDBA to Enhance Engagement}

One of the intriguing aspects of the MDBA's work to date has been the perceived gap between the stated principles of its approach to stakeholder engagement (see Box 26.1) — which appears to coincide with some aspects of what a cooperative or collaborative approach might involve - and what has occurred to date in practice.

\section{Box 26.1 Principles underpinning the MDBA's approach to stakeholder engagement}

Our approach to stakeholder engagement is guided by the following principles upon which we will operate and to which we will be accountable.

We are committed to ensure that our stakeholder engagement is:

- transparent - we will engage with transparent purpose, goals, accountabilities, expectations and constraints

- inclusive and targeted - we will seek to engage with individuals and organisations that represent the full diversity of those who will be affected by the Basin Plan. We will seek to engage Indigenous people and people who have English as a second language in culturally appropriate ways. We will provide opportunities for people with disabilities, including vision and hearing impaired.

- appropriate and adaptive - we will use levels and methods of engagement that suit the group being consulted and our strategy will be adaptive to feedback

- accessible and innovative - we will provide clear, accessible and comprehensive information to people in order to help them understand their engagement with us

- respectful - we will conduct engagement activities in a manner that fosters mutual respect and trust by listening to feedback and responding where possible. We will treat comments and submissions as well as collect and store information in accordance with the Privacy Act 1988(Commonwealth)

- supportive - we will be sensitive to how the changes resulting from the Basin Plan impact individuals. 
Perhaps sensing the growing frustration of stakeholders who were able to access little information about the advances being made on the Draft Murray-Darling Basin Plan, the MDBA made the decision to release a 'Guide' to the Draft Plan. This initiative - a step not originally planned under the Water Act - was seen by the MDBA as an additional voluntary mechanism for engaging stakeholders and giving them a chance to comment on the synthesis and planning option definition it had carried out, as well as to improve its work, before the formal consultation process on the Draft Murray-Darling Basin Plan was held. As stated by the MDBA in its Guide to the proposed Basin Plan:

The objectives of the engagement process for the Guide and proposed Basin Plan are to:

- provide information about the Guide and the proposed Basin Plan

- give opportunities for people to provide feedback on the Guide, to ensure the proposed Basin Plan is based on the best available information

- give opportunities for people to provide feedback on, and input to, the proposed Basin Plan, including through a formal submission process. (MDBA 2010)

The objectives of this process were therefore seemingly aimed at providing a basis for simple information exchange, rather than more interactive or collaborative forms of engagement. The manner in which the main part of this information and consultation program was carried out - the town-hall meeting tour and associated call for submissions - has, however, yet to quell many stakeholders' concerns about the planning process. It rather seems to have added to the frustration and anger of some stakeholders, with scenes of people burning the Guide outside a couple of meetings (Franklin 2010). During the meetings many people also spoke emotionally about their fears and anxieties about the way the planning is being carried out, including that the meetings have done little to enhance their understanding of the science and analysis that underlie the planning propositions presented in the Guide. Many found it particularly disappointing that the technical volume of the Guide was not released prior to the meetings, with this 'hiding' of information considered a reason to distrust the science. Some potential reasons for why this particular initiative of information meetings seemed to receive so many hostile reactions will be investigated later in the chapter after a brief exploration of how collaborative approaches can be developed and the choice of stakeholder-engagement methods can be aided. 


\section{Existing Knowledge of Developing Effective Collaborative Management and Stakeholder- Engagement Approaches}

Considering the need for, and importance of, collaborative approaches and engaging a range of stakeholders from the policy, public and scientific spheres in water planning and management, much research in this domain has occurred over the past three to four decades. Lessons and knowledge about what kinds of processes work in what contexts have been developed from extensive experience and assessment of collaborative management approaches and stakeholderengagement processes around the world. Throughout a range of academic disciplines and management practices, there has been growing concern about working across boundaries (organisational, cultural, political, administrative, and so on) and developing inclusive and stakeholder-informed decision-making processes. For example, there has been a long history of developing 'public participation' in many spheres of public policy, or more deliberative versions of political involvement of citizens in decision-making and knowledge-creation processes - for example, through studies of 'deliberative democracy' or 'social learning' . Breaking down barriers between professionals and other stakeholdersincluding service users in both the public and the private spheres - as well as between organisations has also led to much knowledge and expertise that can be found under a range of appellations, including 'stakeholder participation', 'participatory processes', 'institutional coordination', 'adaptive management', 'collaborative advantage', 'inter-organisational management', 'multi-stakeholder platforms', 'soft systems approaches', 'conflict management' and 'modelling with stakeholders', although many of the key findings are surprisingly similar (Daniell 2008; Huxham 1996; Lynham et al. 2007; Renger et al. 2008; Tan et al. 2008; Voinov and Bousquet 2010). Specifically in the water domain, about 10 years ago, practitioners and scholars were still investigating what was desired from participatory processes in different contexts and what methods could be used to achieve these goals (Dovers 2000). More recently, however, through extensive field testing of methods, a much better understanding of these issues has emerged, and individual designers have been able to engineer processes to reach their desired outcomes (Hare et al. 2006). Numerous guidelines, books and papers on the design and use of participatory methods now also exist (for example, Aslin and Brown 2004; Beierle and Cayford 2002; Creighton 2005; Stern and Fineberg 1996) to help process organisers to achieve a range of desired outcomes. Such guides tend to provide in-depth information on

- stakeholder analysis, including how to identify and select or invite stakeholders to participate

- decision analysis, including how to identify and select the issues to be examined and gather existing knowledge on them 
- participation planning, including the selection of methods for different stages in the decision-making or planning cycle and logistics planning for stakeholder-engagement events (von Korff et al. 2010).

Very recent research and practical processes have focused more strongly on how to increase the efficiency, effectiveness and innovation potential of large-scale or multi-level participatory water-management processes, as well as how to more successfully manage and transform water conflicts. Useful results from such work include a need to focus efforts on constructing effective organisation teams or inter-institutional networks for collectively managing or 'co-engineering' participatory processes to achieve multiple goals, and on the potential for individuals in both formal and informal participatory processes to encourage transitions in governance to more collaborative and adaptive arrangements (Daniell et al. 2010b; Meijerink and Huitema 2010; Moellenkamp et al. 2010). Linked to the importance of a diversity of values present in water-management debates, important work on integrating or adhering to appropriate ethics is also appearing as an aid for preventing and resolving water-related conflicts; and the need to find balanced perspectives will enable more effective cooperation and collaboration for water management to occur (Daniell et al. 2009; Delli Priscoli and Wolf 2009). In particular, for effective and efficient water planning to occur, in-depth reflection and debate over at least two different levels of process and content should ideally occur, as outlined in Table 26.1.

\section{Table 26.1 Two sets of questions to investigate for collaborative water management}

\begin{tabular}{l|l}
\multicolumn{1}{c|}{$\begin{array}{c}\text { Stakeholder process for managing } \\
\text { water systems }\end{array}$} & \multicolumn{1}{c}{$\begin{array}{c}\text { Project organisation process } \\
\text { for managing the participatory } \\
\text { process }\end{array}$} \\
\hline Why ought a water plan be created? & $\begin{array}{l}\text { Who ought to be responsible for organising } \\
\text { and managing the participatory process? }\end{array}$ \\
\hline What ought to be the goals of the water plan? & $\begin{array}{l}\text { How ought the scope and purposes of the } \\
\text { water-management plan be decided? }\end{array}$ \\
\hline What ought to be the actions to achieve these goals? & $\begin{array}{l}\text { How ought the decision be made on who } \\
\text { ought to participate and when? }\end{array}$ \\
\hline $\begin{array}{l}\text { Who ought to be responsible for funding, resourcing } \\
\text { and implementing these actions and when? }\end{array}$ & $\begin{array}{l}\text { Which participatory methods ought to be used } \\
\text { and why? }\end{array}$ \\
\hline $\begin{array}{l}\text { How ought progress towards these goals be } \\
\text { measured? }\end{array}$ & $\begin{array}{l}\text { Who ought to design, implement or } \\
\text { facilitate the use of these methods with the } \\
\text { participants? }\end{array}$ \\
\hline $\begin{array}{l}\text { How ought the plan be adjusted based on these } \\
\text { evaluations? }\end{array}$ & $\begin{array}{l}\text { Who ought to analyse and synthesise the } \\
\text { results stemming from the participatory } \\
\text { process? }\end{array}$ \\
\hline
\end{tabular}


The questions in the first column of Table 26.1 are ideally used to guide discussion and eventually decisions on these issues throughout a collaborative stakeholder process for managing water systems. The questions in the second column of Table 26.1 then refer to how this collaborative stakeholder process might itself be organised, with these questions typically guiding the negotiations and decisions of an organising team, which could include some stakeholders. Further explanation of this differentiation of participatory processes-one with water-planning decisions as a key outcome, and the second having organisational decisions on the development of a collaborative stakeholder process - is provided in Daniell et al. (2010b). Examples of ethical dilemmas and methods of working through them based on some of the questions in Table 26.1 are presented in Daniell et al. (2009). Further tools for working through conflicts and consensus building are provided in Delli Priscoli (2003).

Failing to resolve misunderstandings or conflicts surrounding each of these questions could lead to serious challenges in developing successful collaboration processes and achieving better outcomes through water-management plans. In particular, it is important to note that the answers to the questions are often made unconsciously, with little explicit discussion by those wishing or needing to engage. This 'setting the terms' of engagement - if it is not carried out in a collaborative or at least an open manner - can be one of the main reasons why certain stakeholder groups such as 'the public' or 'citizens' choose to resist invitations to engage. In this chapter, space is not available to discuss typical aids that can be used to elicit and discuss potential answers to all these questions, so just a couple that could be relevant for understanding the current angst over the MDB planning process will be briefly examined in the next section.

\section{Choosing Stakeholder-Engagement Methods and Participants}

The first issue to understand for aiding the choice of what methods can be most effectively used with certain participants is that there is a sliding scale of what can be considered 'engagement' or 'participation'. Many classifications are based on the level of power sharing between decision makers and other stakeholders (for example, Arnstein 1969; Mostert 2003), considering that only processes that have the potential for significant alteration of decision-makers' viewpoints or mutual learning (such as the interactive processes of co-thinking or codeciding) should be called 'participation' or 'engagement'. Other processes, which limit interactive communication and the impact of stakeholders' views on decision making - such as information provision or consultation-are considered to be lesser forms of participation or 'tokenism' (Arnstein 1969). Often due to time and resource constraints, hard decisions on how to limit the extent of participation, but maintain the potential for success, must be made. 
Just one classification aimed at facilitating this choice is presented in Figure 26.1. The classification considers that if, for example, relative to a particular object of interest (for example, a study on a particular topic; implementation planning for specific management actions), stakeholders have potentially high levels of resources available (for example, knowledge, implementation capacity, authority, finance) and a high stake in the decisions related to the object of interest (for example, they will be strongly affected by or could make or block the decision) then they should be actively involved in the 'decision-aiding' process associated with that object. Further explanation of this classification and its use in the design of participatory processes can be found in Mazri (2007) and Daniell et al. (2010a).

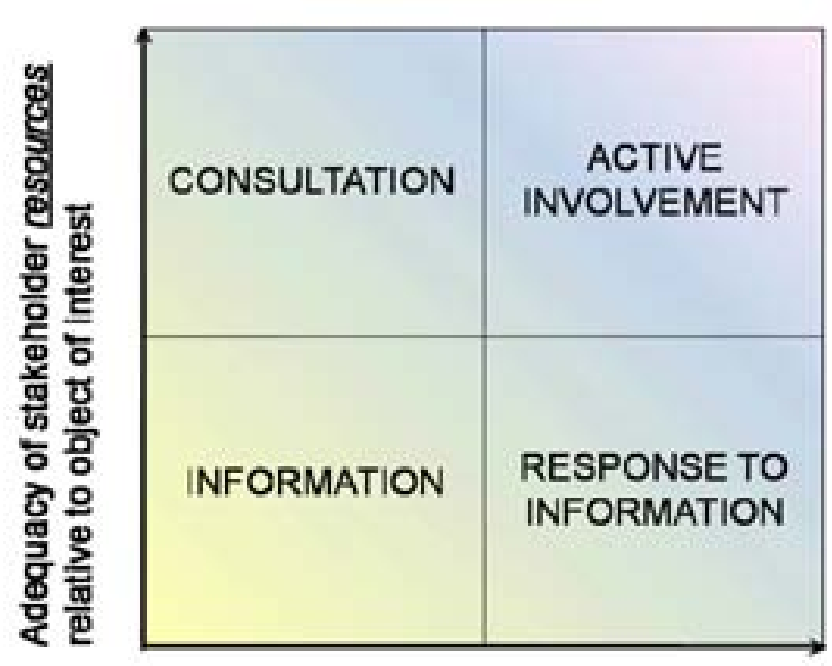

Adequacy of stakeholder stakes relative to object of interest

Figure 26.1 Understanding when to involve stakeholders at different levels of engagement

Source: Mazri (2007).

A second issue to consider prior to choosing methods and participants is the importance of determining the objectives of the engagement, the resources available to support the stakeholder-engagement process, and the phase of the decision-making process in which the methods are to be applied. A number of these are outlined in Table 26.2. The choice of objectives should ideally be strongly linked to the results of reflection on the questions outlined in Table 26.1 . 
Table 26.2 Potential objectives, resources and decision-making phases that can impact on appropriate choice of methods and participants

\begin{tabular}{|c|c|c|}
\hline Objectives & Resources & $\begin{array}{c}\text { Decision-making } \\
\text { phases }\end{array}$ \\
\hline $\begin{array}{l}\text { - Information provision } \\
\text { - Education } \\
\text { - Improving two-way communication } \\
\text { - Social learning } \\
\text { - Enhancing legitimacy of decisions } \\
\text { - Enabling democratic governance } \\
\text { - Conflict resolution } \\
\text { - Legal/organisational requirements } \\
\text { - Building personal relations and social } \\
\text { - } \text { capacity } \\
\text { To achieve a better water- } \\
\text { management outcome }\end{array}$ & $\begin{array}{l}\text { - Time and finance } \\
\text { - Skills in designing and } \\
\text { using methods } \\
\text { - Organisational will and } \\
\text { leadership } \\
\text { - Existing trust levels and } \\
\text { relationships } \\
\text { - Power to make and } \\
\text { implement decisions } \\
\text { - Knowledge of the policy } \\
\text { area } \\
\text { - Stakeholder interest and } \\
\text { capacity in engaging } \\
\text { (both agencies and } \\
\text { communities) }\end{array}$ & $\begin{array}{l}\text { - Identifying and } \\
\text { structuring issues and } \\
\text { values } \\
\text { - Situation analysis } \\
\text { - Eliciting preferences } \\
\text { - Developing and assessing } \\
\text { - management options } \\
\text { - Negotiating choices } \\
\text { - Implementation planning } \\
\text { - Ponitoring and evaluation } \\
\text { Policy and plan } \\
\text { adjustment }\end{array}$ \\
\hline
\end{tabular}

Depending on the objectives, the resources available, and the decision-making phase targeted for the engagement process, different methods can be selected. A number of methods - ranging from less interactive to more interactive - are outlined in Table 26.3, along with what they might ideally be used for, the key challenges associated with the method, its potential cost and how many people can participate. Further discussion of these methods and many more are available in a range of publications (for example, Aslin and Brown 2004; Chambers 2002; Creighton 2005; Forester 1999).

Some methods in Table 26.3 allow for participants to be chosen at will (for example, workshops, Delphi, mail-outs), some are typically open to all (for example, broadcasts, town-hall meetings, some online gaming or forums) and others have specific methodologies for the selection of participants (for example, citizens' juries, consensus conferences or some surveys). Most methods require careful design, implementation and monitoring to ensure that they have the best possible chance of meeting their planned objectives. It is very common for a suite of different methods to be employed with different participants for separate stages of the decision-making process. A range of documents (for example, Aslin and Brown 2004; Daniell 2008; Tan et al. 2008; von Korff et al. 2010) explains how this might be done. A range of expertise is available across Australia and internationally in water management, community development and business that can be mustered for these processes, including facilitators, mediators, decision analysts, communications experts and participatoryprocess management specialists. Nevertheless, despite the best intentions, there are some barriers that can prevent effective stakeholder engagement and collaborative approaches from occurring, and these need to be understood and managed. Examples of barriers for decision makers and scientific experts, and stakeholders and the public, are presented in Table 26.4. 


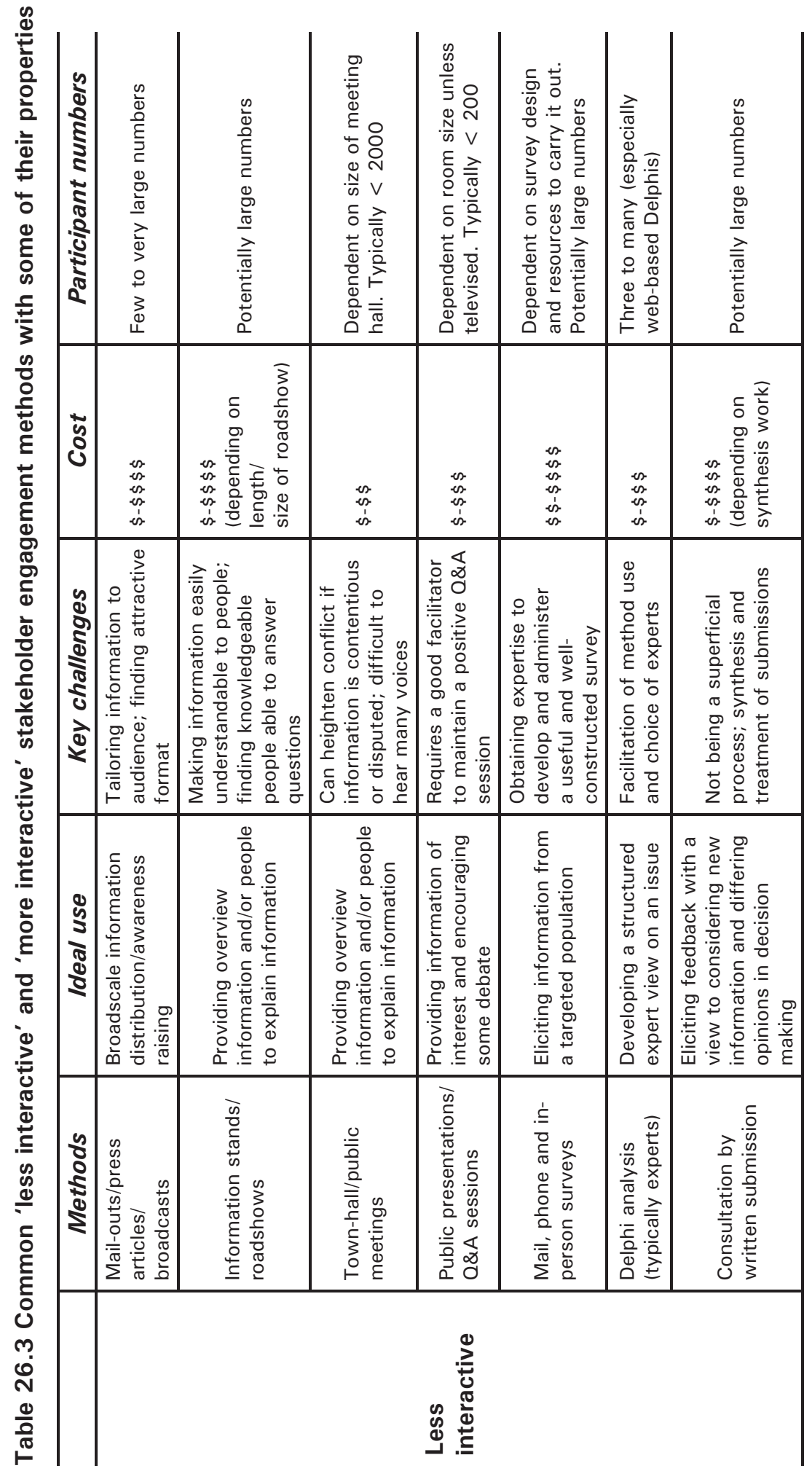




\begin{tabular}{|c|c|c|c|c|c|c|}
\hline 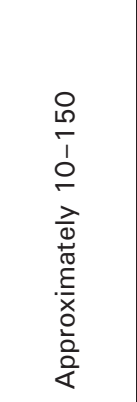 & 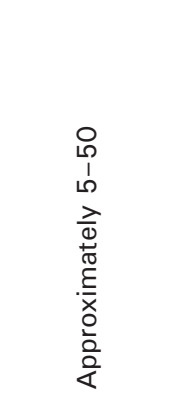 & 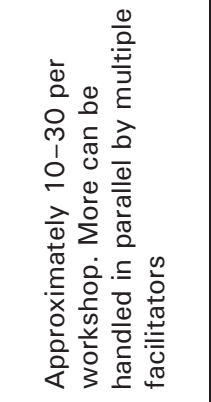 & 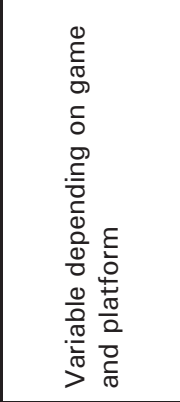 & 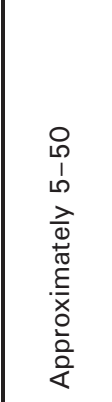 & 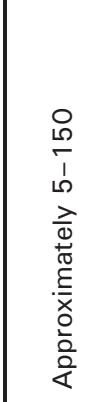 & 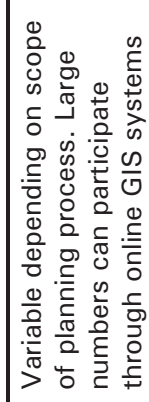 \\
\hline $\begin{array}{l}\infty \\
\infty \\
\infty \\
\infty \\
\infty \\
\infty\end{array}$ & $\begin{array}{l}\text { क } \\
\text { क } \\
\text { कs. }\end{array}$ & $\begin{array}{l}\text { w. } \\
\text { s. } \\
\text {. }\end{array}$ & 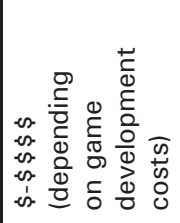 & $\begin{array}{l}\text { क } \\
\text { क } \\
\text { कs }\end{array}$ & $\begin{array}{l}\text { w } \\
\text { w } \\
\text { s. } \\
\text { in }\end{array}$ & $\begin{array}{l}\infty \\
\infty \\
\infty \\
\infty \\
\infty\end{array}$ \\
\hline 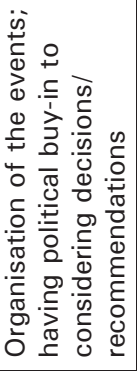 & 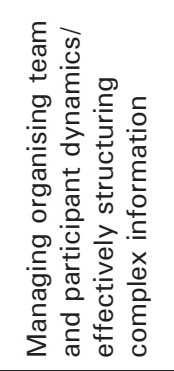 & 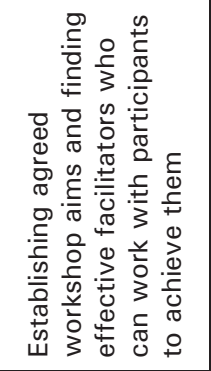 & 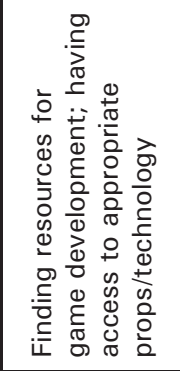 & 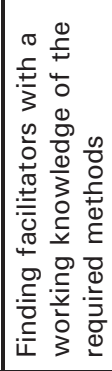 & 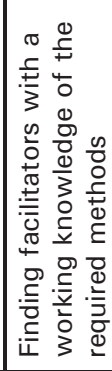 & 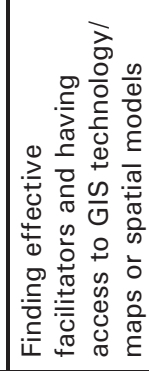 \\
\hline 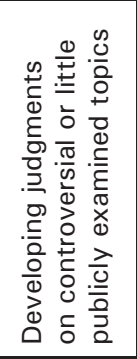 & 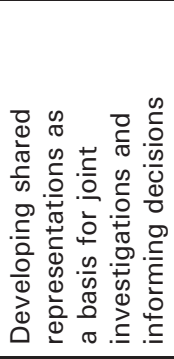 & 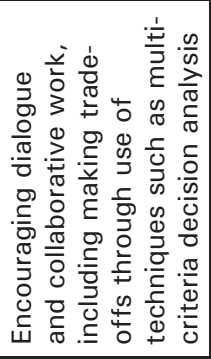 & 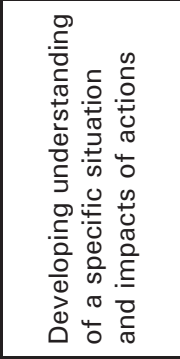 & 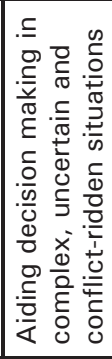 & 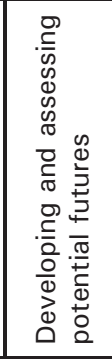 & 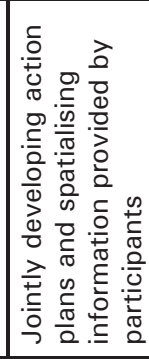 \\
\hline 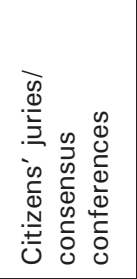 & 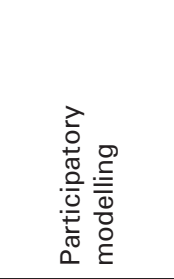 & 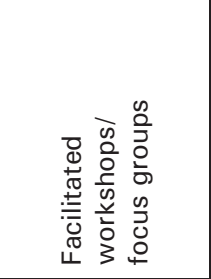 & 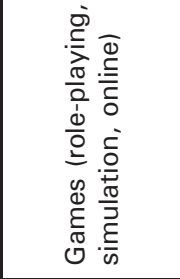 & 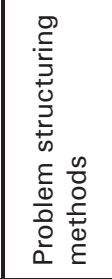 & 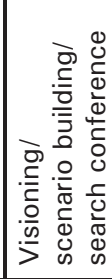 & 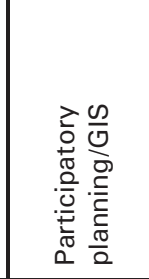 \\
\hline \multicolumn{7}{|c|}{ 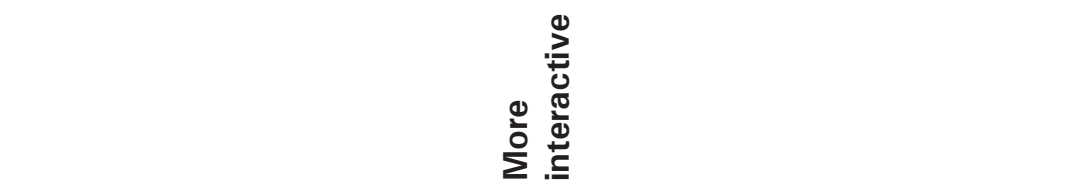 } \\
\hline
\end{tabular}




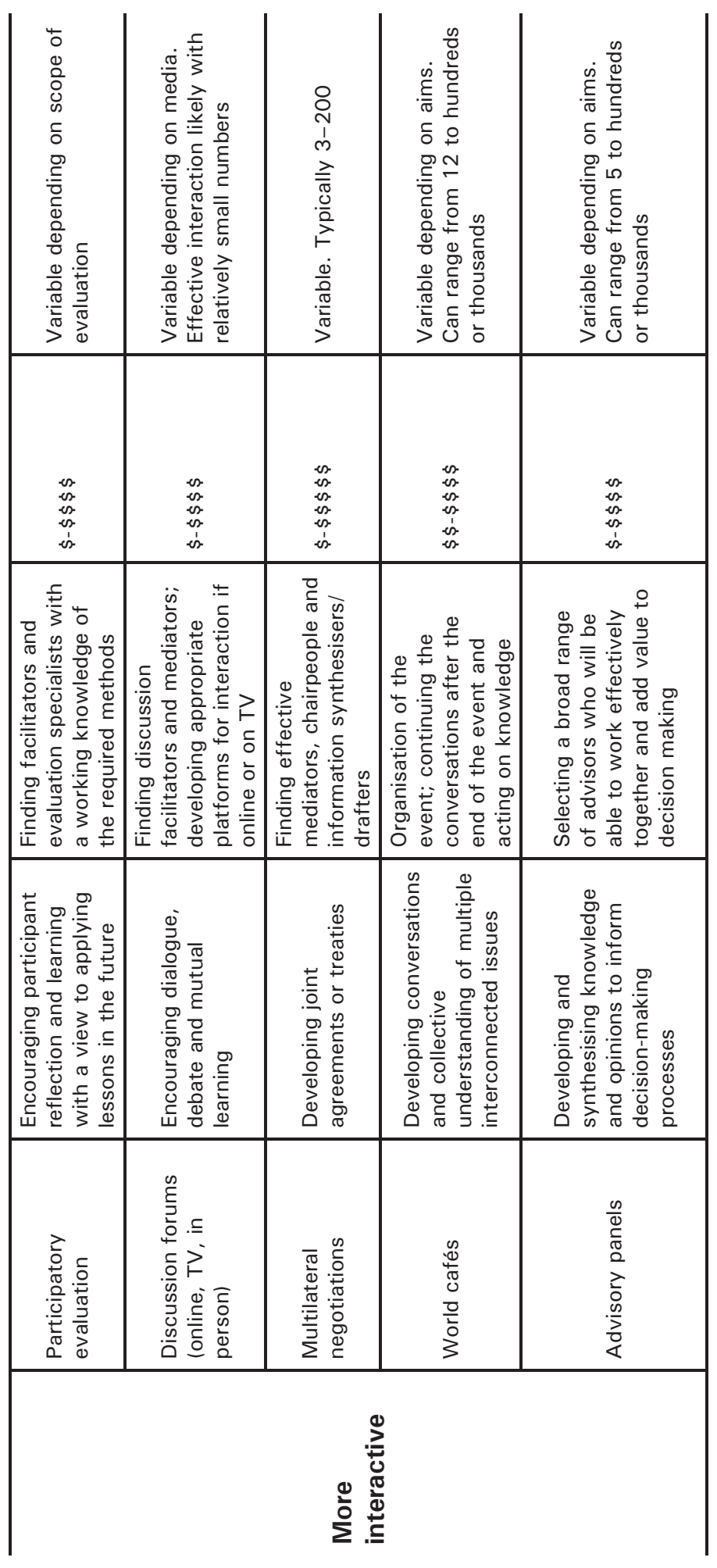


Table 26.4 Barriers to stakeholder engagement and collaborative approaches

\begin{tabular}{l|l}
\hline \multicolumn{1}{c|}{$\begin{array}{c}\text { For decision makers and scientific } \\
\text { experts }\end{array}$} & \multicolumn{1}{c}{ For stakeholders/the public } \\
\hline $\begin{array}{l}\text { Lack of will to involve others in decision and } \\
\text { science processes }\end{array}$ & $\begin{array}{l}\text { Lack of interest or time to become involved } \\
\text { in such processes (especially in an 'out-of- } \\
\text { crisis' period) }\end{array}$ \\
\hline $\begin{array}{l}\text { Lack of organisational support and } \\
\text { leadership }\end{array}$ & $\begin{array}{l}\text { Previous bad stakeholder-engagement } \\
\text { experiences }\end{array}$ \\
\hline $\begin{array}{l}\text { Inadequate resources, including time, } \\
\text { finance, knowledge and a lack of training as } \\
\text { facilitators and with participatory methods }\end{array}$ & $\begin{array}{l}\text { Lack of other resources to participate (for } \\
\text { example, knowledge, technology, financial } \\
\text { support) }\end{array}$ \\
\hline $\begin{array}{l}\text { Lack of personnel continuity (difficulties } \\
\text { building and maintaining relationships and } \\
\text { trust) }\end{array}$ & \begin{tabular}{l} 
Mistrust in coordinators \\
\hline $\begin{array}{l}\text { Inability to manage stakeholder expectations } \\
\text { and conflict }\end{array}$
\end{tabular} \\
\hline $\begin{array}{l}\text { Legal, security or other institutional } \\
\text { constraints }\end{array}$ & $\begin{array}{l}\text { Scepticism that participation will make a } \\
\text { difference }\end{array}$ \\
\hline
\end{tabular}

At this point it is worth acknowledging that if barriers cannot be overcome, it is often better not to try to engage stakeholders than to convene substandard participatory processes that are likely to disappoint stakeholders or lead to 'over-consultation', as more damage than good is likely to result (for further discussion on this point, see Barreteau et al. 2010). In some cases, however, where certain stakeholder inputs and cooperation are required to achieve key desired outcomes of water reform, perseverance to engage and negotiate will be necessary.

\section{Enhancing Collaborative Management and Stakeholder Engagement in the Basin}

In light of this brief analysis of the need for collaborative approaches and some of the methods of stakeholder engagement that can be used to support them, it is now possible to postulate a number of reasons why there appears to be so much anger, frustration and anxiety felt by many stakeholders across the Murray-Darling Basin, and how altering the current management approach could lead to improved outcomes.

\section{Managing Stakeholder Anxiety, Frustration and Anger}

In any important reform process, fear of the unknown typically makes people feel anxious and often defensive towards change. This anxiety is a natural emotional response to a situation in which negative consequences are anticipated (Stephan 
and Stephan 1985). Stakeholders across the MDB recognise that these new water reforms - and in particular the development of the Murray-Darling Basin Plan-represent potentially massive change and could likely threaten their current way of living. Without any convincing and encouraging information to the contrary provided to them before the release of the Guide and all of its supporting documentation, many stakeholders were therefore harbouring a range of negative emotions directed predominantly at the MDBA and the Government. In such a situation - in which stakeholder perceptions of the reforms appear to be deteriorating and associated potentially harmful mental health impacts could be envisaged in the short and longer term - what can be done to improve the reform process?

First, in times of change, leadership is the key for providing a vision of the future that can be positively anticipated, even if short-term pain is part of that vision as being a necessary part of the transition. Showing the importance of the gap between the vision and what maintaining the status quo could represent can help to galvanise support for action and planning to work towards a preferred future. Linked to this process, anxiety over uncertainty can be mitigated by providing more certainty and attempting to build trust. One way of working on this uncertainty reduction and trust building is to provide and explain the consequences of information as soon as it comes to hand, so that people can understand the reasons for the situation. Also, knowing that support will be available to help manage any negative consequences can reduce anxiety, as it is also a means of understanding options and reducing uncertainty. The key here is 'understanding'. A good example of how to do this was provided by the Queensland Premier, who held regular press conferences with other leaders from the Police and the Army in the lead-up to, and during, the recent flood and cyclone crises, to explain the situation, relay information from scientists, clarify what actions were being taken to manage the situation and what affected people could do, and empathise with people and reassure them that everything possible would be done to help them cope with any consequences of the extreme events. As with anxiety, the effective management of anger, frustration and disappointment typically requires people to be able to 'let out' their emotions in a safe environment and have the opportunity to be understood. Building mutual understanding of these emotions and being shown the respect and willingness to work through the root causes of these emotions will eventually build more positive emotions and capacity to cope with the situations presented. So, to what extent was the choice made by the MDBA to release the Guide and couple it with a series of town-hall meetings likely to succeed in improving the reform?

From Table 26.3, it can be seen that although town-hall meetings can be used for informing relatively large numbers of people about a limited range of issues at low cost (compared with other methods), they present the challenge of 
potentially heightening conflict if the information is controversial or disputed. They are also not typically appropriate for fostering two-way conversations, understanding and trust that are required to overcome negative emotions. Informed participatory-process analysts would therefore most likely have predicted that, given the mood of stakeholders in the Basin before the release of the Guide, the proposed engagement process was likely to inflame rather than calm tensions. If, however, the sessions were led exceptionally well by charismatic, convincing communicators with an attractive vision of the Basin and in-depth knowledge of the science underlying the planning decisions, some improvements in stakeholder sentiment could have occurred.

In terms of other relatively low-cost stakeholder-engagement approaches that could lead to more favourable outcomes, there are some options available. For example, given that the anxieties are in part linked to the Basin Plan and lack of understanding of the knowledge and assumptions underlying it, one approach potentially more adapted to this specific issue could include a 'roadshow' with MDBA scientific staff manning a stand/caravan for a period in each key regional centre where they have all of the data, information and studies to help stakeholders to gain understanding of the issues that interest them most and to build trust with the MDBA on a more personal basis. This would, however, be only a small part of a larger process needed to rebuild and further enhance all stakeholders' confidence, understanding and collective capacity to work together across a range of geographical and administrative scales. Developing a potentially valuable and acceptable collaborative-management approach, with a range of appropriate stakeholders and stakeholder-engagement methods employed, would require much thought, concerted effort, finance and, more importantly, engagement with a range of stakeholders to determine their needs, constraints and aspirations for the current and future phases of the MDB planning process.

\section{Looking to the Future: Strengthening leadership and collaborative practice}

Hope remains across the Basin that the recent reforms will lead to a brighter future for the Basin and the communities it supports, even if this hope is currently tempered by a range of negative emotions, and many communities are trying to cope with the impacts of floods after many years of drought. It is well known that positive changes can take place when people feel the need to act, and are respected and encouraged in their efforts. The 2010-11 flood crisis across large parts of Australia has shown us that with good leadership, timely and continuous information provision, empathy, trust in others' capacities and putting efforts into coordination and support, many Australians will rise to a challenge and are more than willing to volunteer and to work together through 
extremely difficult and potentially devastating situations. We should learn from this experience and determine how it can be reapplied to build a positive future for the Basin. Generosity and goodwill in aiding adjustment processes can soften the blow of loss and provide a foundation for resilient and positive communities and individuals to get back on their feet after tumultuous change. Lessons and knowledge available from other MDB, Australian and international experiences can also be gleaned on how communities can use collaborative values-focused processes to plan for the future, including large cuts to water allocations (see, for example, Richardson et al. 2011, (chapter 22)), estuarine risk management (Daniell et al. 2008) and flood and drought risk management (Daniell et al. 2011).

With a new Chairman of the MDBA having just been appointed and the Parliamentary Inquiry drawing to a close, a window of opportunity is available for the Federal Government to lead the MDB planning process in a new direction. This direction would ideally set the enabling governance conditions that would allow: 1) a clear vision for the Basin to be articulated; and 2) communities, regions, and State and Federal governments to come together in a broad collaborative effort to propose ways of restructuring the Basin for the future. Informally starting development of the State water-resource plans before the Basin Plan is finalised could provide a concrete basis for assessing the potential basin-wide impacts of planning decisions. The keys to this endeavour would be to

- acknowledge that decision making associated with the MDB Plan is based on values, objectives and specific visions for the future, as well as science

- lead a well-resourced collaborative approach to the next phase of plan development to actively engage all stakeholder groups, including all existing management agencies, in an inclusive and respectful manner, where real dialogue can occur on a vision for the Basin, achievable plan objectives, scientific and stakeholder knowledge, development of management options and their impacts under a range of scenarios, potential adjustment packages and monitoring plans

- work to engage stakeholders in ways they want to be engaged (as far as possible), with a commitment made to value their input and support them through the decision-making and implementation phases of the reforms.

This collaborative approach would provide a basis for a Basin Plan that could: a) adequately value the river-basin system along with the people managing and relying on it for their livelihoods; b) better ensure that the Plan is based on the best available scientific and stakeholder knowledge; and c) allow stakeholders to develop ownership of the Plan and prepare for changes through its implementation. 


\section{Conclusions}

This chapter has outlined that for the desired outcomes of the Murray-Darling Basin reform process to be reached, the centralised technocratic approach of the MDBA with minimal levels of interactive engagement with stakeholders is inappropriate. Rather, investment is required in a more collaborative approach to the reforms where the best available science and experience from practice on participatory processes should be drawn upon. Town-hall meetings should not be the main engagement method used in a collaborative approach; rather, a range of interactive and less interactive methods needs to be employed. Such an approach could include a range of regional and local panels, facilitated workshops that include visioning activities and participatory planning based on scenarios of potential futures. These would complement the information gathering and consultation already carried out through the responses to the Guide to the proposed Basin Plan and the current Parliamentary Inquiry. Learning from the recent flood and cyclone crises in Queensland, holding regular official press conferences with the relevant ministers and the Chair of the Murray-Darling Basin Authority, and potentially using larger panels of community, government and scientific leaders for Q\&A sessions might also aid in showing leadership, rebuilding trust and demonstrating the priority accorded to this important national endeavour. Acknowledging that the Government and communities are working together to reduce the negative impacts of the reforms and that support will be made available to those affected through potentially difficult transitions could help people to rebuild a sense of pride in being a part of these significant new reforms. It would provide the impetus to many stakeholders to engage or drive the process at their level, allowing them to offer their knowledge and energy to make the new measures a success in securing a viable and sustainable future for the Basin.

\section{Acknowledgments}

Thank you to the Fellows, Friends and supporters of the Peter Cullen Trust for many thought-provoking discussions, which have inspired a number of reflections presented in the chapter, as well as to an anonymous reviewer for comments and suggestions that have improved its structure and clarity.

\section{References}

Arnstein, S. R. 1969, 'A ladder of citizen participation', Journal of American Institute of Planners, vol. 35, pp. 216-24. 
Aslin, H. J. and Brown, V. A. 2004, Towards Whole of Community Engagement: A practical toolkit, Murray-Darling Basin Commission, Canberra, <http:// publications.mdbc.gov.au/download/towards_whole_of_community_ engagement_toolkit.pdf>

Barreteau, O., Bots, P. W. G. and Daniell, K. A. 2010, 'A framework for clarifying "participation" in participatory research to prevent its rejection for the wrong reasons', Ecology and Society, vol. 15, no. 2, art. 1, <http://www. ecologyandsociety.org/vol15/iss2/artl/>

Beierle, T. C. and Cayford, J. 2002, Democracy in Practice: Public participation in environmental decisions, Resources for the Future, Washington, DC.

Bellamy, J., Ross, H., Ewing, S. and Meppem, T. 2002, Integrated catchment management: learning from the Australian experience for the Murray-Darling Basin, Report prepared for the Murray-Darling Basin Commission, CSIRO Sustainable Ecosystems, Canberra, <http://www2.mdbc.gov.au/_data/ page/911/ICM_Learning_from_Australian_Experience.pdf $>$

Boully, L. 2004, Participatory governance: intra and inter governmental consultation and community engagement in the Murray-Darling Basin Initiative, Presented to Seventh Annual Corporate Governance in the Public Sector Conference, Canberra, 20-22 April 2004.

Chambers, R. 2002, Participatory Workshops: A sourcebook of 21 sets of ideas and activities, Earthscan, London.

Connell, D. 2007, Water Politics in the Murray Darling Basin, The Federation Press, Leichhardt, NSW.

Connick, S. and Innes, J. 2001, Outcomes of Collaborative Water Policy Making: Applying complexity thinking to evaluation, Institute of Urban and Regional Development, University of California, Berkeley.

Crase, L., Dollery, B. and Wallis, J. 2005, 'Conceptualising community consultation in public policy formulation: the case of the Living Murray debate in the Murray Darling Basin of Australia', Australian Journal of Political Science, vol. 40, pp. 221-37.

Creighton, J. L. 2005, The Public Participation Handbook: Making better decisions through citizen involvement, Jossey-Bass, San Francisco.

Daniell, K. A. 2008, Co-engineering participatory modelling processes for water planning and management [Co-ingénierie des processus de modélisation participative pour la planification et la gestion de l'eau], (2 vols), PhD Thesis, The Australian National University, Canberra, and AgroParisTech, Montpellier, France. 
Daniell, K. A., Coad, P., Ferrand, N., White, I., Jones, N., Guise, K., Marvell, C., Burn, S. and Perez, P. 2008, Participatory values-based risk management for the water sector, Paper presented at the Proceedings of the Water Down Under 2008 Conference, Adelaide, 14-17 April 2008.

Daniell, K. A., Mazri, C. and Tsoukiàs, A. 2010a, 'Real world decision-aiding: a case of participatory water management', in D. Rios Insua and S. French (eds), e-Democracy: A group decision and negotiation perspective, Springer, Dordrecht, pp. 125-50.

Daniell, K. A., Ribarova, I. S. and Ferrand, N. 2011, 'Collaborative flood and drought risk management in the Upper Iskar Basin, Bulgaria', in R. Q. Grafton and K. Hussey (eds), Water Resources Planning and Management, Cambridge University Press, UK, pp. 395-420.

Daniell, K. A., White, I., Ferrand, N., Riborova, I. S., Coad, P., Rougier, J.-E., Hare, M., Jones, N., Popova, A., Perez, P. and Burn, S. 2010b, 'Coengineering participatory water management processes: theory and insights from Australian and Bulgarian interventions', Ecology and Society, vol. 15, no. 4, art. 11, <http://www.ecologyandsociety.org/vol15/iss4/art11/>

Daniell, K. A., White, I. and Rollin, D. 2009, 'Ethics and participatory water planning', Proceedings of the 32nd Hydrology and Water Resources Symposium: 'H2009', 30 November - 3 December 2009, Newcastle, Australia, pp. 1476-87.

Davidoff, P. 1965, 'Advocacy and pluralism in planning', Journal of American Institute of Planners, vol. 31, no. 4, pp. 331-8.

Delli Priscoli, J. 2003, Participation, Consensus Building, and Conflict Management Training Course (Tools for Achieving PCCP), United Nations Educational, Scientific and Cultural Organisation-International Hydrological Programme prepared for the WWAP, Paris.

Delli Priscoli, J. and Wolf, A. T. 2009, Managing and Transforming Water Conflicts, Cambridge University Press, UK.

Dietz, T., Ostrom, E. and Stern, P. C. 2003, 'The struggle to govern the commons', Science, vol. 302, pp. 1907-12.

Dovers, S. 2000, 'Beyond everythingcare and everythingwatch: public participation, public policy, and participating publics', Proceedings, International Landcare 2000 Conference, Department of Natural Resources and Environment, Melbourne.

Dryzek, J. S. 1990, Discursive Democracy: Politics, policy and political science, Cambridge University Press, New York. 
Fischer, F. 1990, Technocracy and the Politics of Expertise: Critical perspectives on the managerial and policy sciences, Sage Publications, Newbury Park, Calif.

Fischer, F. 2000, Citizens, Experts, and the Environment, Duke University Press, Durham, NC.

Forester, J. 1999, The Deliberative Practitioner: Encouraging participatory planning processes, MIT Press, Cambridge, Mass.

Franklin, M. 2010, 'Heated backlash forces Murray inquiry', The Australian, 15 October 2010.

Gleick, P. H. 2000, The World's Water 2000-2001: The biennial report on freshwater resources, Island Press, Washington, DC.

Hare, M. P., Barreteau, O., Beck, M. B., Letcher, R. A., Mostert, E., Tàbara, J. D., Ridder, D., Cogan, V. and Pahl-Wostl, C. 2006, 'Methods for stakeholder participation in water management', in C. Giupponi, A. J. Jakeman, D. Karssenberg and M. P. Hare (eds), Sustainable Management of Water Resources: An integrated approach, Edward Elgar, Chichester, UK, pp. 177-225.

Huxham, C. (ed.) 1996, Creating Collaborative Advantage, Sage Publications, London.

Ingram, H. and Schneider, A. 1999, 'Science, democracy, and water policy', Water Resources Update, vol. 133, pp. 21-8.

International Conference on Water and the Environment (ICWE) 1992, The Dublin Statement on Water and Sustainable Development, International Conference on Water and the Environment, Dublin.

Landry, M., Banville, C. and Oral, M. 1996, 'Model legitimisation in operational research', European Journal of Operational Research, vol. 92, no. 3, pp. 44353.

Loucks, D. P. 1998, 'Watershed planning: changing issues, processes and expectations', Water Resources Update, Universities' Council on Water Resources, no. 111 (Spring), Carbondale, Ill., pp. 38-45.

Lynham, T., de Jong, W., Sheil, W., Kusumanto, T. and Evans, K. 2007, 'A review of tools for incorporating community knowledge, preferences and values into decision making in natural resource management', Ecology and Society, vol. 12, no. 1, art. 5, <http://www.ecologyandsociety.org/voll2/iss1/art5/>

Margerum, R. D. 2008, 'A typology of collaboration efforts in environmental management', Environmental Management, vol. 41, pp. 487-500. 
Marshall, G. R. and Stafford Smith, D. M. 2010, 'Natural resources governance for the drylands of the Murray-Darling Basin', The Rangeland Journal, vol. 32, pp. 267-82.

Mazri, C. 2007, Apport méthodologique pour la structuration de processus de décision publique en contexte participatif. Le cas des risques industriels majeurs en France, Université Paris Dauphine, France.

Meijerink, S. and Huitema, D. 2010, 'Policy entrepreneurs and change strategies: lessons from sixteen case studies of water transitions around the globe', Ecology and Society, vol. 15, no. 2, art. 21, <http://www.ecologyandsociety. org/vol15/iss2/art21/>

Moellenkamp, S., Lamers, M., Huesmann, C., Rotter, S., Pahl-Wostl, C., Speil, K. and Pohl, W. 2010, 'Informal participatory platforms for adaptive management. Insights into niche-finding, collaborative design and outcomes from a participatory process in the Rhine basin', Ecology and Society, vol. 15, no. 4, art. 41, <http://www.ecologyandsociety.org/vol15/iss4/art4l/>

Mostert, E. 2003, 'The European Water Framework Directive and water management research', Physics and Chemistry of the Earth, vol. 28, nos 1213, pp. 523-7.

Murray-Darling Basin Authority (MDBA) 2009, Stakeholder Engagement Strategy, Murray-Darling Basin Authority, Canberra, <http://www.mdba. gov.au/files/publications/Stakeholder-Engagement-Strategy-brochure.pdf>

Murray-Darling Basin Authority (MDBA) 2010, Guide to the proposed Basin Plan. Volume 1: Overview, Murray-Darling Basin Authority, Canberra.

Nandalal, K. D. W. and Simonovic, S. P. 2003, State-of-the-Art Report on Systems Analysis Methods for Resolution of Conflicts in Water Resources Management, UNESCO-IHP.

Renger, M., Kolshoten, G. and De Vreede, G. 2008, 'Challenges in collaborative modelling: a literature review and research agenda', International Journal of Simulation and Process Modelling, vol. 4, pp. 248-63.

Standing Committee on Environment and Heritage (SCEH) 2000, Co-ordinating Catchment Management: Report of the Inquiry into Catchment Management, Standing Committee on Environment and Heritage, House of Representatives, The Parliament of the Commonwealth of Australia, Canberra.

Stephan, C. and Stephan, W. 1985, 'Intergroup relations', in G. Lindzey and E. Aronson (eds), Handbook of Social Psychology, [Third edition], Random House, New York. 
Stern, P. J. and Fineberg, H. V. (eds) 1996, Understanding Risk: Informing decisions in a democratic society, National Academy Press, Washington, DC.

Syme, G. J. and Hatfield-Dodds, S. 2007, 'The role of communication and attitudes research in the evolution of effective resource management arrangements', in K. Hussey and S. Dovers (eds), Managing Water for Australia: The social and institutional challenges, CSIRO Publishing, Collingwood, Vic., pp. 11-22.

Tan, P. L., Jackson, S., Oliver, P., Mackenzie, J., Proctor, W. and Ayre, M. 2008, Collaborative Water Planning: Context and practice literature review, Land \& Water Australia, Canberra, <http://wa.gov.au/files/products/track/ pn21213/pn21213.pdf>

Thomas, R. L. 2004, 'Management of freshwater systems: the interactive roles of science, politics and management, and the public', Lakes and Reservoirs: Research and Management, vol. 9, no. 1, pp. 65-73.

Voinov, A. and Bousquet, F. 2010, 'Modelling with stakeholders', Environmental Modelling \& Software, vol. 25, pp. 1268-81.

von Korff, Y., d'Aquino, P., Daniell, K. A. and Bijlsma, R. 2010, 'Designing participation processes for water management and beyond', Ecology and Society, vol. 15, no. 3, art. 1, <http://www.ecologyandsociety.org/vol15/ iss $3 / \operatorname{artl} />$

Wong, P. 2008, Water for the future, Speech to the Fourth Annual Australian Water Summit, Sydney Convention and Exhibition Centre, Sydney, 29-30 April 2008. 